\title{
The environmental impacts of eletronic wastes in bayelsa state, Nigeria
}

\begin{abstract}
Anthropogenic activities associated with electronic wastes pose deleterious effects to the ecosystem. The uncontrolled combustion of electronic wastes in public places and their subsequent eco-toxicity is becoming worrisome. This study assess the deleterious effects posed by electronic wastes. Portable metres were used to assess water and air quality, while Atomic Absorption Spectrophotometer was used to assess the heavy metals. Results showed that wind speed ranges from $1.57 \pm 0.29-4.18 \pm 1.06 \mathrm{~m} /$ $\mathrm{s}$, carbon monoxide $(0.01 \pm 0.00-2.13 \pm 0.30 \mathrm{ppm})$, Oxides of Sulphur $(0.01 \pm 0.00$ $0.51 \pm 0.17 \mathrm{ppm})$, Oxides of Nitrogen $(0.01 \pm 0.00-0.34 \pm 0.63 \mathrm{ppm})$, Total Suspended Particulate was in the range of $59.56 \pm 3.17-76.32 \pm 5.13 \mu \mathrm{g} / \mathrm{m} 3(\mathrm{p}<0.05)$. The $\mathrm{pH}$ of the recipient water body was $4.31 \pm 1.13-5.93 \pm 1.37$, Turbidity ranged from $33.61 \pm 5.59$ $-69.08 \pm 6.13 \mathrm{NTU}$, with COD ranging from $3.39 \pm 0.72-5.79 \pm 7.13 \mathrm{mg} / \mathrm{l}$. Besides Iron (1.75 $\pm 0.04-3.73 \pm 0.07 \mathrm{mg} / \mathrm{l})$ and Zinc $(0.05 \pm 0.03-1.61 \pm 0.11 \mathrm{mg} / \mathrm{l})$, other heavy metals like Copper, Cadmium, Mercury, Chromium, Arsenic and Selenium were below detection limit $(\mathrm{p}<0.05)$. Generally, results indicated mild anthropogenic impact with likelihood of rising above permissible limits. As such there is need to consistently monitor anthropogenic activities, and deter offenders through effective legislation and enforcement.
\end{abstract}

Volume 4 Issue 5 - 2018

\author{
Tariwari C.N Angaye,' Odangowei I Ogidi, ${ }^{2}$ \\ Godbless N Oyinke ${ }^{3}$ \\ 'Department of Biological Science, Niger Delta University, \\ Nigeria \\ ${ }^{2}$ Department of Family Medicine, Niger Delta University \\ Teaching Hospital, Nigeria \\ ${ }^{3}$ Department of Science Laboratory Technology, Nigeria
}

\author{
Correspondence: Tariwari CN Angaye, Department of \\ Biological Science, Faculty of Science, Niger Delta University, \\ Wilberforce Island, Bayelsa State, Nigeria
}

Email maktarry@yahoo.com

Received: February 08, 2018 | Published: october 01,2018

\section{Introduction}

Electronic wastes (E-waste) are solid superfluous or ready to be discarded materials arising from electrical and/or electronic devices. It also includes obsolete and discarded electronic equipment at endof-life stage. ${ }^{1,2}$ Electronic wastes includes but not limited to cell phones, televisions, MP3 Players, and computers (Terada, 2012). In Nigeria, the rise of E-waste stream is due to the purchase of shortspanned or second-hand electronics, ${ }^{3}$ as well as the yearning of the populace to keep abreast with contemporary technologies. ${ }^{4}$ Electronic wastes have been found to contain diverse deleterious elements such as; lead, mercury, beryllium, cadmium, chromium and brominated flame retardants, to mention but a few. ${ }^{3}$ Anthropogenic activities arising from E-waste poses grave consequences on the ecosystem. In most cases the mobility of E-waste toxicants is further escalated by their insitu burning thereby releasing toxic substances to the air, soil and well as bottom sink in aquatic ecosystem. Yenagoa metropolis is a capital city of Bayelsa State and forms part of the Niger Delta Region of Nigeria. The region is a wetland characterized by high level of precipitation and hence prone to flooding. Consequent upon the fragility of the ecosystem, the environmental Impact of E-Waste in Yenagoa is hereby evaluated.

\section{Methodology}

\section{Meteorology, air quality and heavy metals}

Air quality, heavy metals and some meteorological parameters were monitored in 5 stations (including control), at the Electronic village in Etegwe popularly known as Tombia Junction. Meteorological parameter like; wind speed was measured using portable hand-held Kestrel meteorological meter (4500NV-USA). The sampling stations were geo-referenced using Germin etrex GPS (Taiwan). Some pollutant gases like; Carbon monoxide (CO), Hydrogen sulphide $\left(\mathrm{H}_{2} \mathrm{~S}\right)$, Oxides of Sulphur (SOx) and Nitrogen (NOx), were measured using portable multiprobe AEROQUAL metre was used (Aeroqual Limited Auckland-New Zealand-Series 300).

\section{Statistical analysis}

Analysis of variance (ANOVA) was used for the statistical analysis. Data were expressed as Mean \pm Standard Deviation. The Post-Hoc used for significant mean comparison was Duncan's multiple range test $(\mathrm{P}<0.05)$.

\section{Result and discussion}

As presented in Figure 1, the level of wind speed ranged from $1.57 \pm 0.75-4.18 \pm 1.23 \mathrm{~m} / \mathrm{s}$, compared to the control station with value of $3.33 \pm 0.09 \mathrm{~m} / \mathrm{s}(\mathrm{p}<0.05)$. The highest level of wind speed during the dry season was recorded in station A. Meanwhile, the lowest value was reported in station $\mathrm{D}$. In addition, the wind direction was predominantly in the south-west direction. Results of some pollutant gases associated with the E-Waste sites showed that, the levels of Carbon monoxide (CO) ranges from $0.01 \pm 0.00-2.13 \pm 0.11 \mathrm{ppm}(\mathrm{p}<0.05)$. Furthermore, the highest level of $\mathrm{CO}$ was in station $\mathrm{B}$, with the lowest station $\mathrm{C}$ (Figure 1). In addition, the control station indicated no emission of carbon monoxide as result was below detection limit of the equipment as presented in Figure 1.

As presented in Figure 1, oxides of sulphur $\left(\mathrm{SO}_{\mathrm{x}}\right)$ associated with the E-waste stream were in the range of $0.01 \pm 0.00-0.51 \pm 0.10$ ppm. Highest level of $\mathrm{SO}_{\mathrm{x}}$ was indicated in Station C. On the other hand, lowest level of $\mathrm{SO}_{\mathrm{x}}$ was indicated in station $\mathrm{B}$, and was below detection limit. In addition, level of $\mathrm{SO}_{\mathrm{x}}$ was also below detection limit in the control station. The concentration of nitrogen oxides (NOx) ranges from $0.11 \pm 0.00-0.34 \pm 0.03 \mathrm{ppm}$, with highest 
and lowest values in stations $\mathrm{C}$ and A respectively (Figure 1). In addition, the control station indicated no level of NOx emission. Total Suspended Particulate matter (TSP) amongst the sampling stations ranges from $59.56 \pm 3.17-76.32 \pm 5.13 \mu \mathrm{g} / \mathrm{m}^{3} \quad(\mathrm{p}<0.05)$. The highest value of TSP associated with the sampling stations was indicated in station A. Meanwhile the lowest TSP level was reported in Station B. In addition TSP level in the control station was lowest. All values of TSP complied with regulatory limit the recommended TSP value by the Nigerian Federal Ministry of Environment is $\leq 250 \mu \mathrm{g} / \mathrm{m}^{3} / 24$ hours.

As presented in Figure 2, the $\mathrm{pH}$ of the receiving water body in the study area was acidic and ranged from $4.31 \pm 1.13-5.93 \pm 1.37$. The lowest (Most acidic) $\mathrm{pH}$ was reported in $\mathrm{B}$. on the other hand, the highest $\mathrm{pH}$ was reported in station $\mathrm{C}$. In addition $\mathrm{pH}$ of the control station was almost neutral. Turbidity ranged from $33.61 \pm 5.59$ $-69.08 \pm 6.13 \mathrm{NTU}$, with highest and lowest values in stations D and A respectively (Figure 2). Chemical Oxygen Demand (COD) ranging from $3.39 \pm 0.72-5.79 \pm 7.13 \mathrm{mg} / 1$ was reported in the recipient water body of the study area (Figure 2). Highest and lowest COD values were reported in stations B and A respectively As presented in Figure 3 , heavy metal analysis in recipient water bodies of the study area shows that Besides Iron $(1.75 \pm 0.04-3.73 \pm 0.07 \mathrm{mg} / \mathrm{l})$, and Zinc $(0.05$ $\pm 0.03-1.61 \pm 0.11 \mathrm{mg} / \mathrm{l})$, other heavy metals like Copper, Cadmium, Mercury, Chromium, Arsenic and Selenium were below detection limit $(p<0.05)$. Iron enrichment in the study area is due to lithogenic phenomena rather than anthropogenic activities. ${ }^{5}$ Our finding is comparable with other studies on air quality. A study in Delta state by Rim-Rukeh, ${ }^{6}$ reported SPM values of $773-801 \mu \mathrm{g} / \mathrm{m}^{3}$, CO $(133.7-141.6$ ppm), SOx and NOx were in the range of 21.0-27.3 and 27.7-37.1ppm respectively. In Ebonyi state; carbon monoxide (1.74-1.90 ppm), and NOx in the range of $0.05-0.12 \mathrm{ppm}$ were reported. ${ }^{7}$ In Port-Harcourt city, using particulate analyser the spatial micron levels of suspended particulate matter were reported as; PM0.3 $\left(25.50-58.26 \mu \mathrm{g} / \mathrm{m}^{3}\right)$, PM0.5 (1.61-8.48 $\left.\mu \mathrm{g} / \mathrm{m}^{3}\right)$, PM1.0 (0.35-0.66 $\left.\mu \mathrm{g} / \mathrm{m}^{3}\right)$, PM2.0 (0.16$\left.1.3 \mu \mathrm{g} / \mathrm{m}^{3}\right)$ and PM5.0 which was in the range of $2.6-11.96 \mu \mathrm{g} / \mathrm{m}^{3} .8$ Cases of bronchial constriction, pulmonary resistance, irritation of the mucous membrane, vision impairment red eyes have been reported as a result of inhalation of pollutant gases. ${ }^{9}$ When anthropogenic activities persist, pollutant become bioavailable and induce toxicity to biodiversity. ${ }^{10}$

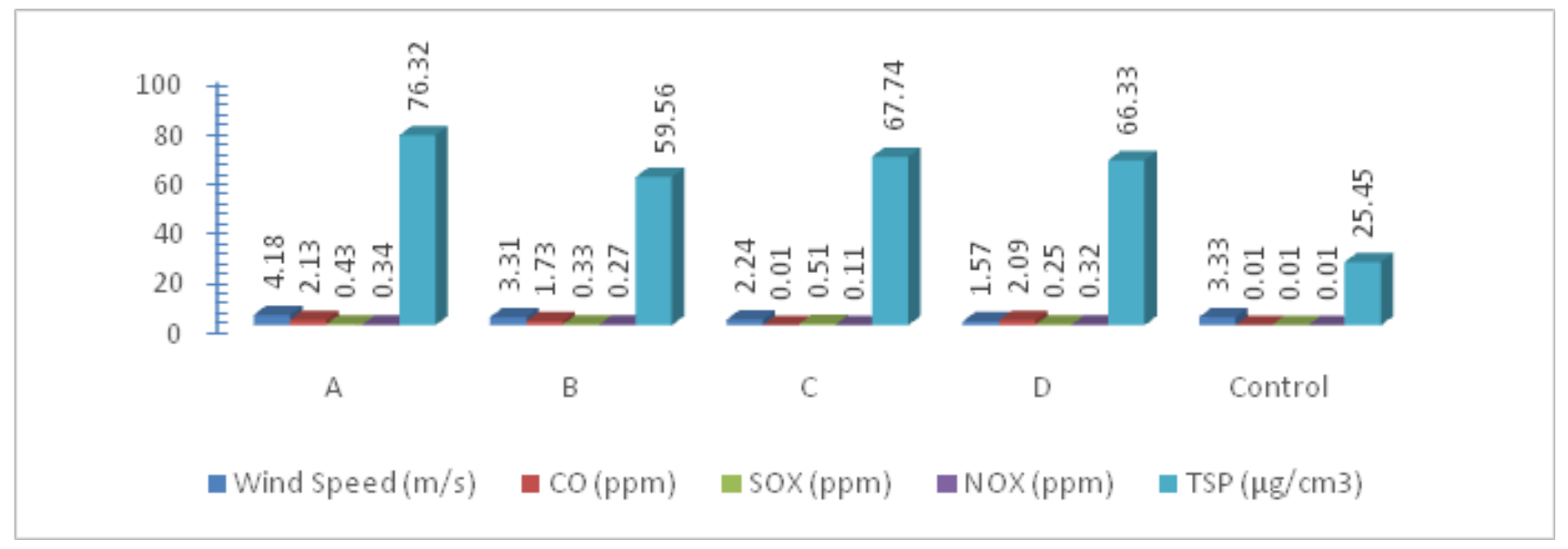

Figure I Spatial variation of wind and air quality.

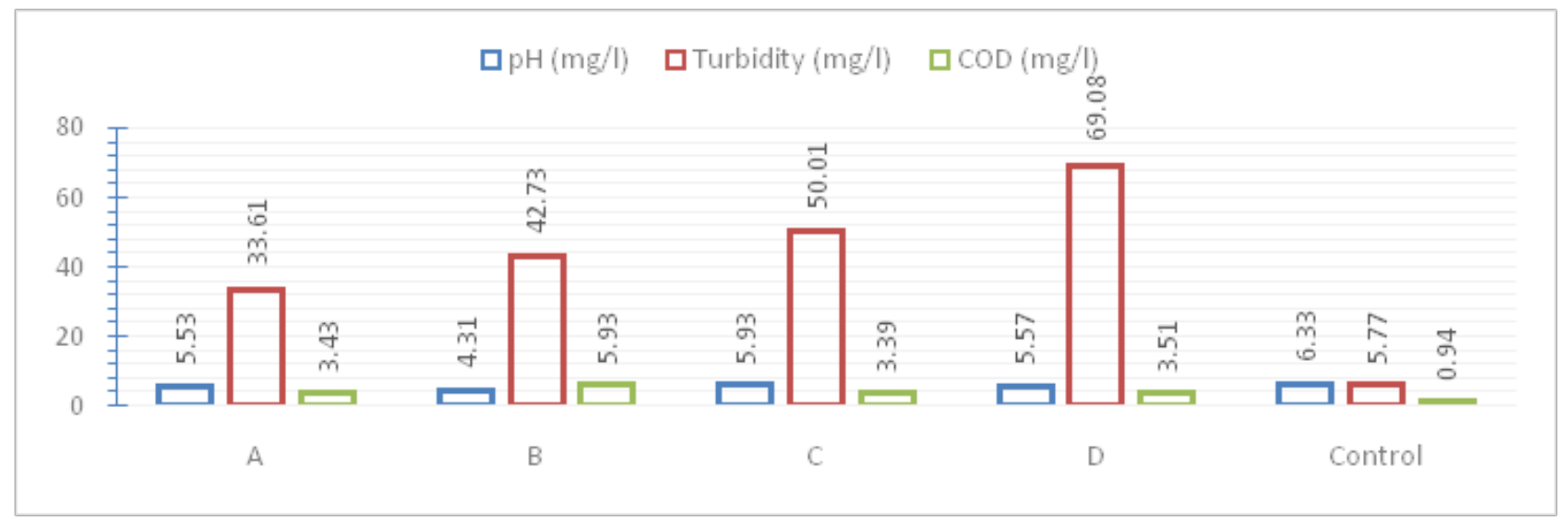

Figure 2 Physicochemical properties of the recipient water body. 


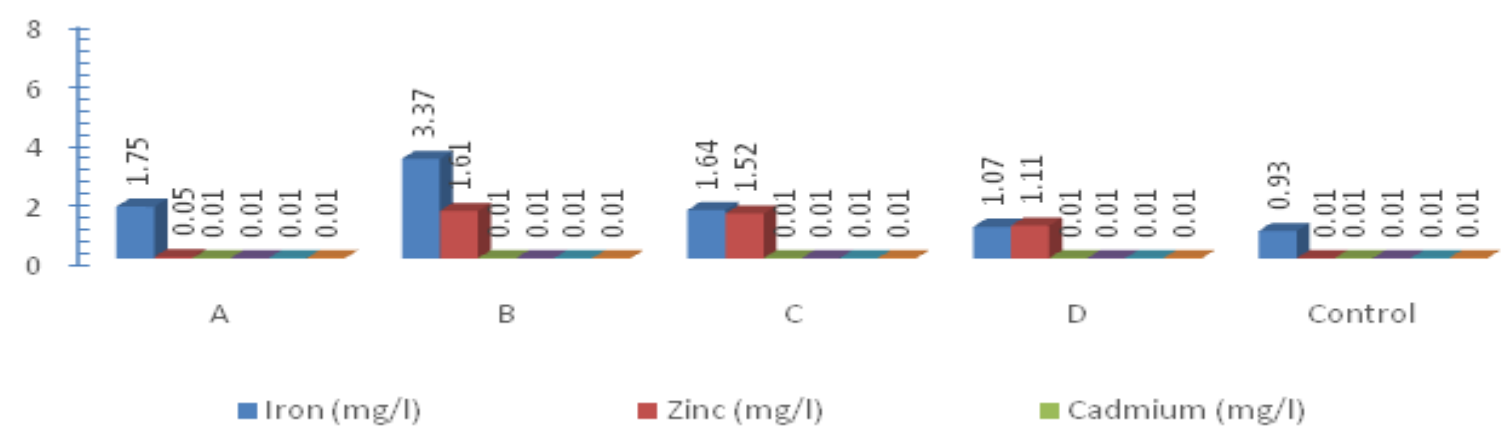

Figure 3 Heavy metals associated with the Electronic wastes

\section{Conclusion}

Generally, mild level of anthropogenic impact of E-waste have been reported in this study. Notwithstanding, we encourage the populace, stakeholders and Government to show more commitment in checking anthropogenic activities associated with E-Waste and formulate sustainable polies that will ameliorate the adverse effects.

\section{Acknowledgements}

None.

\section{Conflict of interest}

The authors declare that there is no conflict of interest.

\section{References}

1. Ogungbuyi O, Nnorom IC, Osibanjo O, et al. E-waste Africa Project of the Secretariat of the Basel Convention. E-waste country assessment Nigeria. 2012. p. 94.

2. Benebo NS. Status of e-waste control in Nigeria. NESREA Presentation at the Workshop on E-Waste in West Africa, Accra: Ghana; 2009. p. 22.

3. Obaje SO. Electronic Waste Scenario in Nigeria: Issues, Problems and Solutions. International Journal of Engineering Science Invention. 2013;2(11):31-36
4. Angaye TCN, Abowei JFN. Evaluation of suspended particulate matter (SPM) around municipal solid waste dumpsites in yenagoa metropolis, Nigeria. MOJ Toxicol. 2018;4(2):54-57.

5. Ohimain EI, Angaye TCN. Iron Levels, Other Selected Physicochemical and Microbiological Properties of Earthen and Concrete Catfish Ponds in Central Niger Delta. Int J Biol Biomed Sci. 2014;3:041-043.

6. Rim Rukeh A. An Assessment of the Contribution of Municipal Solid Waste Dump Sites Fire to Atmospheric Pollution. Open Journal of Air Pollution. 2014;3:53-60.

7. Njoku C. Effect of Waste Dumpsites on Water and Air Qualities in Abakaliki, Southestern Nigeria. International Journal of Plant \& Soil Science. 2014;4(5):455-460.

8. Ezekwe CI, Agbakogba A, Igbagara PW. Source gas emission and ambient air quality around the eneka co-disposal landfill in Portharcourt, Nigeria. International Journal of Applied Chemistry and Industrial Sciences. 2016;2:11-23.

9. ATSDR, Landfill Gas Primer Department of Health and Human Services Agency for Toxic Substances and Disease Registry Division of Health Assessment and Consultation Air and Waste Management Association. Landfills; 2012.

10. Seiyaboh EI, Angaye TCN. Bioavailability of Some Heavy Metals Associated With Municipal Solid Waste Dumpsites in Yenagoa Metropolis, Nigeria. J Med Toxicol Res. 2018;1:11-15. 